\title{
A ORIGEM DA UNIVERSIDADE DE PARIS (I):
}

\author{
RUY AFONSO DA COSTA NUNES \\ Assistente do Setor de Fllosofia e História da Educação. \\ Departamento de Educaçáo da Faculdade de Fllosofia \\ Ciências e Letras da Universidade de Sáo Paulo. \\ "Je crois ... que c'est seulement en étu- \\ diant avec soln le passé que nous pourrons \\ arriver a anticlper l'avenir et a compren- \\ dre le présent, et que, par suite, une his- \\ toire de I'enselgnement est la melleure \\ des écoles pédagogiques". \\ Durkhetm, L'évolution pédagogique en \\ France, pág. 12-13.
}

\section{CAPITULO I.}

\section{QUESTÕES INTRODUTORIAS.}

O objetivo desta monografia é examinar a origem da Universidade de Paris.

Foi no princípio do século XIII que a Universidade começou a organizar-se. Em 1200, por um privilégio outorgado por Filipe Augusto, a corporação dos professôres e dos estudantes de Paris passou a reger-se pela jurisdição eclesiástica, furtando-se dessa maneira ao fôro civil. Em 1215, Roberto de Courçon, legado pontifício, concedeu ao studium parisiense seus primeiros estatutos oficiais. Se tais medidas constituíram o início da organização jurídica da Universidade, foram, por outro lado, o remate de um lento processo de formação. Mas, como decorreu êsse movimento germinativo da Universidade de Paris? Que condições o prepararam e que fatôres contribuíram para sua gênese e desenvolvimento?

Essa, a questão que me proponho a examinar.

Não me interessa, por conseguinte, estudar a expansão, o apogeu da Universidade nos séculos XIII e XIV, nem pretendo perquirir a origem de outras universidades. 
A Universidade de Paris, como já se observou, ainda está à espera de seu historiador. Enquanto isso não ocorre, êste ensaio pode ser apreciado com indulgência, pois não passa de cometimento despretensioso, tendo a ampará-lo o socôrro das boas obras de referência. Entretanto, confesso ter envidado todos os esforços para chegar às fontes. Para isso consultei os autores do século XII que pude haver à mão, só não recorrendo a uma fonte de primeira ordem, como o Chartularium Universitatis Parisiensis, por tratar-se de obra que se não encontra em nosso meio e a meu alcance. Restou-me, todavia, o consôlo de poder utilizar a obra de Denifle (1), um dos compiladores do Chartularium, e que fornece referências a manuscritos não editados até hoje.

Isto posto, fica assentado que a época por mim considerada neste trabalho, abrange o século XII, século em que se reuniram as condições e se integraram os fatôres que permitiram a organização da Universidade de Paris, cidade que "fornece com as Artes os pães que alimentam os fortes" (2), Paris, a "cidade feliz", que no dizer de Filipe de Harveng (3), pode merecidamente ser chamada civitas litterarum, a cidade das letras, Paris, que aparecia a Guilherme, o Bretão (4), como "a mestra do mundo inteiro".

\section{II}

Para quem estuda a história do século XII e verifica as transformações da vida social e política, o progresso das idéias filosóficas, a renovação da vida religiosa, o aparecimento da literatura vernácula, a eclosão de novos estilos artísticos, a inauguração de novas instituições, enfim, para quem examina de ânimo desprevenido a intensidade da vida e as grandes mudanças da época, não resta dúvida de que houve um "renascimento" do século XII, ainda mais pela atenção, que no plano do espírito, se dedicou às obras do pensamento antigo. Pode-

(1). - Denifle (Heinrich), Die Entstehung der Universitäten des Mittelalters bis 1400, Graz, Akademische Druck. U. Verlagsanstalt, 1956, 814. págs,

(2). - "In morbis senat medici virtute Salernum.

Aegros. In causis Bononia legibus armat.

Nudos. Parisius dispensat in artibus illos

Panes, unde cibat robustos. Aurelianis

Educat in cunis autorum lacte tenellos".

Geoffroy de Vinsauf, Poetria Nova, v. 1008-1012. Apud Paré, Brunet, Tremblay, La Renaissance du XIIe Siècle, Les Ecoles et l'Enseignement, Refonte complète de l'ouvrage de G. Robert (1909), Paris, Libr. Phllosophique J. Vrin, 1933, 324 págs.

(3) . - Philippus de Harveng, Epistola III, Philippi ad Heroalaum, P. L. (Migne), T. 203, cl. $31 \mathrm{C}$.

(4). - Filipda, I. V. 100-101 apud Halphen, Les origines de l'Université de Paris in "Aspects de l'Université de Paris", Editions Albin Michel, Paris, 1949, 266 págs. 
se asseverar mesmo, com Gilson (5), que se não houve ciência medieval pròpriamente dita, houve certamente um humanismo medieval, elemento essencial da Idade Média, e do qual o do Renascimento não passou, sob certos aspectos, de continuação e de desabrochamento. Por isso, parece-me ocioso estar-se a discutir se houve ou não houve renascimento no século XII, se o que houve não foi renascimento, mas "Renovação ou Florescimento ou Despertar, Réveil, Revival, etc." (6). De fato, existe na História um Renascimento por antonomásia, o ribombante acontecimento cultural do início da Idade Moderna. Nada impede, entretanto, que se denominem de renascimento outros acontecimentos de nomeada no plano cultural, que tenham empolgado a uma época inteira na história de certos povos. Isto equivale a reconhecer que o têrmo renascimento possui uma conotação sociológica, que the permite exprimir certos fenômenos dinâmicos globais de renovação das estruturas sociais, especialmente ligadas a uma retomada da tradição clássica e a um projeto de arranque cultural. A expressão renascimento, então, é equissonante com o "tempo-eixo" a que se refere Jaspers (7), se lhe retirarmos o ca-

(5). - Essais d'Art et de Philosophie, Etienne Gilson, Les Idées et les Lettres, Deuxlème édition, Librairie Philosophique J. Vrin, Paris, 1955, 298 págs. Sôbre o humanismo medieval consulte-se alnda: Gerald G. Walsh, S. J., Humanismo Medioeval, Buenos Aires, La Espiga de P. Oro, 1943, 155 págs.; Les Classiques de l'Humanisme, Paul Renucci, L'Aventure de L'Humanisme Européen au Moyen-Age (IVe-XIVe siècle) - I - Paris, Société d'Édition Les Belles Lettres, 1953, 266 págs., I, chap. II, pág. 68.

(6). - Cf. William A. Nitze, The So-called Twelfth Century Renaissance, in "Speculum", A Journal of Mediaeval Studies, Vol. 23, number 3, July 1948, págs. 464-471: "There are some of the reasons why, as a mediaevalist, I prefer to render unto Cesar the things that are Caesar's and to leave the term Renaissance to the Renatssance"; Frederick Eby and Charles Flinn Arrowood, The History and Philosophy of Education Ancient and Medieval, Englewood Cliffs, N. J., Prentice-Hall, Inc., 1960, 966 págs., Chap. 16, The Flowering of the Midale Ages, pág. 715; Histoire de la Spiritualité Chrétienne - II - Dom Jean Leclercq, Dom François Vandenbroucke, Louis Bouyer, La Spiritualité du Moyen Age, Paris, Aubler, 1961, 718 págs., 2e. Partie, Ch. I, pág. 275: "Il faut donc parler de réveil plutôt que de renaissance du XIIe siècle"; Paul Renucci, obr. cit., chap. II, pág. 54; por fim, Johan Nordström, Moyen Age et Renaissance, Essai historique, Paris, Publications du Fonds Descartes, Librairie Stock, 1933, 238 pág., referindo-se apenas à "renovação da cultura" e ao humanismo do século XII em França, consagra todo o livro a redarguir à tese de Burkhardt, procedente da velha teoria dos humanistas: "barbárie da 1dade média e regeneração da cultura pelo renascimento das artes e das ciências na Itália", pág. 22. Segundo Nordström (Avant-propos, pág. 8), "Pour apprécier exactement la nature et l'importance de la Renaissance italienne, 11 importe de la considérer comme un moment dans l'évolution continue d'un ensemble de civilisation européen. La Renaissance itallenne n'est pas une victolre remportée sur le "moyen âge", elle ne constitue pas une rénovation de la vie civilisée et de l'humanité grâce à une réssurrection de la culture antique. Elle este elle-même une branche fleurle sur l'arbre puissant de ia culture médiévale".

(7). - Karl Jaspers, Von Ursprung und ziel der Geschichte, Origen y Meta de la Historia, Segunda edición, Madrid, Revista de Occidente, 1953, 307 págs. 
ráter absoluto e singular que o filósofo the atribui no início de sua obra, e se meditarmos, no caso do século XII, nas consequiências de seu renascimento para a história do Ocidente e, em ricochete, para a história da cultura humana em geral.

Parece-me, portanto, que o título da famosa obra de Haskins (8), O Renascimento do Século XII, já constitui uma conquista pacífica na terminologia histórica contemporânea.

Assim sendo, vale notar que o movimento escolar do século XII, que prepara a organização da Universidade de Paris, não foi um efeito do renascimento da época, mas um de seus fatôres, bem como a Universidade vem a ser o seu fruto normal (9).

Aliás, durante a Idade Média podem-se observar vários reflorescimentos, como o renascimento carolíngio, o renascimento otoniano, e êste de que estamos tratando, o do século XII. Todavia, foi êste último o mais notável e que, por isso mesmo, também é chamado, como diz Haskins, o Renascimento Medieval.

\section{III}

O Renascimento do século XII surgiu de um conjunto de fatôres que se vinham conjugando desde o período carolíngio. A restauração das letras e dos estudos levada a efeito por Carlos Magno, sob a orientação do monge Alcuino, está na origem dos acontecimentos que, entrosando-se, irão culminar um dia no entusiasmo pela dialética, na dedicação ao estudo e na multiplicação das escolas de Paris.

As péssimas condições sociais da vida no século $\mathrm{X}$, oriundas das invasões e pilhagens dos normandos, eslavos, húngaros e sarracenos vêm acentuar e consagrar o sistema político do feudalismo, que começara a surgir nos tempos dos merovíngios. O feudalismo caracteriza-se pelas relações entre o senhor e o vassalo, pelos serviços que êste presta àquêle em troca de proteção. Ao cavaleiro o suzerano concede o feudo e ao camponês o direito de cultivar a terra em seus domínios. As relações entre o senhor e o vassalo serão por vêzes tão intrincadas como a que foi responsável pelas lutas entre a França e a Inglaterra durante a Idade Média. O feudalismo, como sistema político, embora surgindo no período merovíngio, entra a ca-

Jaspers, no cap. 8 da $1^{a}$ parte, alude a um segundo tempo-eixo constituido pelas extraordinárias criaçōes espirituais da Europa de 1500 a 1800, fenómeno puramente europeu. Ora, nada impede que nos apropriemos da expressão para designar outro fenômeno tipicamente europeu como o renascimento do século XII.

(8). - Charles Homer Haskins, The Renaissance of the Twelfth Century, New York, Meridian Books, 1957, 437 págs.

(9). - Paré, Brunet, Tremblay, ob. cit., cap. IV, pág. 138. 
racterizar-se durante a administração carolíngia, atingindo seu apogeu entre os séculos XI e XIII, mas datando também dêsse tempo os germes de sua decadência com o início da centralização monárquica em que se empenhou a dinastia dos Capetos.

As redes do sistema feudal colheram naturalmente em suas mathas os membros da Igreja. Rei e barões estendem sua proteção interesseira a bispados, mosteiros e paróquias, chamando a si o direito de eleger bispos, abades e de escolher os párocos, colocando desta arte à testa dos cargos eclesiásticos pessoas de sua confiança. Muitas vêzes, preferiam a tal expediente, assumir direta e pessoalmente o manêjo dessas funções para auferirem lucros das rendas e benefícios da Igreja. Essa situação deprimente de abadias, mosteiros, bispados e paróquias constituiu o foco de muitos males e de incriveis abusos para a vida religiosa. Indivíduos sem formação, destituídos frequientemente de senso moral, sem vocação para o ministério, arvoravamse em diretores de almas e pastores do rebanho cristão. Daí a origem da Querela das Investiduras, pois os reis e principalmente os Imperadores Germânicos julgam ser de seu direito investir nas funções de bispos e abades aquêles que eram seus vassalos e dependentes hierárquicos, com o que não se conformam os Papas, ciosos de suas prerrogativas espirituais e da correção dos costumes cristãos.

Tais abusos do sistema feudal no plano religioso vão, por sua vez, provoçar a reação reformadora, primeiro do clero regular, representado especialmente pelos beneditinos de Cluny (10), e em seguida dos Papas como Gregório VII. Essa reação benéfica e necessária levou, de um lado, à federação dos mosteiros beneditinos sob a orientação de Cluny, cujo impulso reformador se irradiou por tôda a Cristandade, e, de outro, à centralização romana, sendo que os Papas franceses Urbano II, Pascoal II e Calixto II fizeram triunfar os ideais de Gregório VII e a tese de Ivo de Chartres (11) durante o século XII. Outra consequiência dessa reforma empreendida pelos Papas com o desiderato de fazer os fiéis volverem às origens da fé e dos costumes cristãos, foi a renovação do clero secular promovida através dos Con-

(10). - A respeito dêsses assuntos de históría religiosa recorremos principalmente a Delaruelle-Latreille-Palanque, Histoire du Catholicisme en France, I, Des Origines a la Chrétienté Médiévale, Paris, Editions Spes, 1957, 351 págs. O mosteiro de Cluny, sempre independente do poder secular e da autoridade eclestástica, resultou da doação de um domínio feita por Guilherme III, duque de Aquitânia, a Bernão, abade de Baume, a 2 de setembro de 909, e seu prodigloso desenvolvimento iniciou-se com o abade Odão em 927. Pequena referência também em G. Ambroise, Les Moines au Moyen-Age, Leur influence intellectuelle et politique en France, Paris, A. Picard, Editeur, 1946, 248 págs.

(11) - - A tese chartrense a propósito das Investiduras: à Igreja a cura animarum, ao principe os regalia, desde que não os confira junto com o báculo. Cf. Delaruelle-Latreille-Palanque, ob. cit., pág. 287. 
cílios e, principalmente, através da criação das comunidades de cônegos. Os clérigos seculares, desejosos de vida mais perfeita, mas não querendo tornar-se monges; pretendendo viver nas cidades, nas aldeias, nas estradas sem precisarem enclaururar-se num mosteiro, vão optar por um tipo de vida comunitária regida pela Regra (Cânon - canônico - cônego) de Santo Agostinho, bem ampla e flexível para tôdas as adaptações que se afigurassem necessárias. O movimento canônico, estimulado e abençoado com privilégios por Gregório VII, tomou impulso desde 1059, quando o Papa Nicolau, no mesmo Sínodo em que acometeu pela primeira vez contra a investidura leiga, convidou o clero secular a viver canônicamente. As fundações canônicas multiplicaram-se na segunda metade do século XI. São Capítulos das Catedrais estabelecidos nas sedes diocesanas e cujos membros elegiam os bispos; são Colegiais, de influência puramente local, fundadas por benfeitores desejosos de orações em seu favor; são comunidades paroquiais em que se congregam sacerdotes pobres sequiosos de perfeição espiritual, mas que pretendem viver no mundo e não em mosteiros; são também leigos, que se tornam cônegos e, de acôrdo com seu ideal de perfeição, vão consagrar-se aos desvalidos, aos doentes, aos peregrinos em hospitais ou hospícios. Logo os estabelecimentos canônicos se reúnem em congregações com o a de São Vitor (12) e a dos Premonstratenses (13). Não deixaram de surgir conflitos entre monges e cônegos, pois, além do mais, êstes usavam títulos de tradição monástica para os superiores e para os estabelecimentos, como: abade, mosteiro, etc. Tais conflitos foram arbitrados por uma bula de Urbano II, em 1092, na qual o Papa reconhece a eqüivalência dos gêneros de vida de monges e cônegos. Estes vão desempenhar tarefas que as novas condições sociais estavam a exigir e às quais os monges não podiam atender: vão controlar as estradas, proporcionando assitência religiosa e material aos peregrinos; vão construir igrejas novas e divulgar estilos arquitetônicos; vão dedicarse aos labores paroquiais como os Premonstratenses de São Norberto ou à vida intelectual e contemplativa, rigorosamente litúrgica, como os

(12) . - No início do século XII, Guilherme de Champeaux ingressou na Abadia de São Vitor, situada na encosta da colina de Santa Genoveva ... "Ce qu'il importe de noter, c'est que Saint-Victor, comme d'ailleurs les fondations contemporaines de chanoines réguliers, dont il est l'un des plus beaux exemplaires, est à rattacher religieusement, intellectuellement, et institutionneliement, aux formules nouvelles de congrégations de cieros qu'inspirent les transformattons de la société et le renouveau de la culture". Cf. Paré, Brunet, Tremblay, ob. cit., págs. 37-38.

(13). - Fol na floresta de Coucy que, em 1120, s. Norberto fundou o primeiro mosteiro premonstratense. Fliche-Martin, Histoire de l'kglise, T. 9, Augustin Fliche-Raymonde Foreville-Jean Rousset, Du Premier Concile du Latran à l'Avènement d'Innocent III (1123-1198), Paris, Bloud et Gay, 1948, 204 págs. Cf. pág. 127. 
Vitorinos de Paris, cuja escola se tornará, to século XII, um centro de fulguração cultural e de intensa vida religiosa.

Durante o século XII a renovação espiritual prossegue com o extraordinário impulso que São Bernardo imprime à ordem de Cister (14), assim como pela es:antosa influência que êle exerceu sôbre a vida da Igreja e sôbre os acontecimentos políticos da época.

\section{IV}

A 27 de novembro de 1095, décimo dia do Concílio de Clermont, na França, era anunciada a primeira Cruzada, acontecimento de tantas conseqüências políticas, econômicas e culturais para os destinos do Ocidente. Foi o início da grandiosa epopéia de fé e heroismo, que adiou por três séculos a queda de Constantinopla e o fim do Império Romano do Oriente. Esse fim principiara em 1055, quando Toghrul-beg, o Seldjúcida, entrou em Bagdá e "se impôs ao califa árabe como vigário temporal e sultão, superpondo assim ao império árabe um império turco, quando, com êle, os turcos se tornaram a raça imperial do mundo muçulmano" (15). Senhores da Armênia, do Egito, de Antioquia, Jerusalém, Nicéia, massacrando os cristãos e ameaçando os Estreitos, os turcos apareciam como um perigo iminente para a segurança e a paz do Ocidente. $O$ grito de "Deus o quer" foi a resposta vibrante dos guerreiros cristãos ao apêlo de Urbano II em prol da mobilização européia contra a ameaça dos turcos. De 1060 a 1077, o normando Roberto Guiscardo conquistou lentamente a Sićlia aos muçulmanos, estabelecendo na Itália meridional um reino normando, que logo mais se constituirá em ponte cultural entre o Oriente e o Ocidente.

De 1060 a 1070, Guilherme, o Bastardo, torna-se o histórico Conquistador pela conquista normanda da Inglaterra, que durante muito tempo será uma filial das instituições francesas e também uma sementeira de sábios que ela exportará para Paris durante o século XII.

A partir de 6 de maio de 1085, as tropas de Afonso VI apoderam-se de Toledo, em breve a capital dos tradutores, e dominam tôda a região entre o Douro e o Tejo. Tal feito espanhol foi levado a cabo com o auxílio de cavaleiros normandos, borguinhões, proven-

(14). - Cister (Citeaux), o local mais obscuro e selvagem de uma floresta perto de Châlons, foi o local escolhido por Roberto de Molesmes para criar um nôvo mosteiro, bêrço da ordem cisterciense, onde a regra de são Bento fósse fielmente observada: Allbe Luddy, Bernardo de Claraval, tradução de Eduardo Saló, Lisboa, Editorial Aster, 1959, 607 págs. Cf. págs. 29 e seguintes.

(15). - Collection Historia XIII, Le Club Meilleur Livre, René Grousset, L'Epopée des Croisades, Ch. I, Paris, Librairie Plon, 1958, 265 págs. 
çais, languedocianos, gascões, aquitânios, aos quais, desde 1063, o Papa Alexandre II concedera indulgências, se lutassem na Espanha.

As Cruzadas concorreram para o desenvolvimento das cidades italianas, especialmente Veneza, Pisa e Gênova. Nas pegadas dos guerreiros iam os comerciantes e armadores, que reiniciaram, após séculos, o grande tráfico não só das especiarias, do açúcar, dos perfumes, do marfim e das pedras preciosas, como das matérias primas, indispensáveis para os artesãos europeus: sêda, algodão, madeiras, resinas, goma-laca, etc. Renasce então na Europa, principalmente no norte da França, na Flandres, a atividade comercial e industrial, que desperta as cidades de seu torpor multissecular. Elas também permitiram novos contactos culturais assim como contribuiram para o aumento dos conhecimentos geográficos. Todos êsses acontecimentos tão sumàriamente apresentados são de importância fundamentalâ para o aparecimento das . Universidades, e por isso não podiam ser omitidos neste trabalho. Mas ainda restam outros fatos e serem focalizados. E êstes são os fatos econômicos, que na França condicionaram imediata e diretamente a origem e o desenvolvimento da Universidade de Paris .

Stephen d'Irsay fala explìcitamente das causas da Universidade de Paris. Denifle refere-se ao fatôres que contribuiram para sua formação. Arrowood (16) menciona as condições altamente favoráveis $\mathrm{e}$ as condições essenciais para a origem das universidades. Quer se diga causa ou fator, condições ou circunstâncias (17), parece-me que vale a pena insistir aqui numa distinção filosófica entre causa e condição. Isto serve para evitar confusões e mistificações.

Como se verifica pelo estudo da história, o elemento econômico é fundamental no processo do desenvolvimento humano. Penso, entretanto, que a exclusiva importância atribuída ao fator econômico (18) advém de uma apreensão parcial das necessidades do homem.

(16). - Eby-Arrowood, ob. cit., págs. 756, 758.

117). - Comumente confunde-se na linguagem o uso de expressóes como condiçăo e circunstância, embora, filosòficamente seja possível distingui-las. Posso, por exemplo, dispor de tôdas as condiçóes para escrever uma carta com tôda tranquỉlidade. Certas circunstâncias, entretanto, uma súbita visita, um chamado inesperado podem colbir-me essa tarefa.

(18). - Em carta a Joseph Bloch (Londres, 21 de setembro de 1890) diz Engels: “...D'après la conception matérialiste de l'histoire, le facteur déterminant dans l'histoire est, en dernière instance, la production et la reproduction de la vie réelle. Ni Marx ni mol n'avons jamals affirmé davantage. Si ensuite, quelqu'un torture cette proposition pour lui faire dire que le facteur économique est le seul determinant, il la transforme en une phrase vide, abstraite, absurde". Engels prossegue aftrmando que a situação eco- 
Realmente, o trabalho, o esfôrço pela sobre :ivîncia, a luta pelo alimento, pelo vestuário, pela habitação ocorrem em virtude de nossas necessidades orgânicas, físicas, $c$ então o fato econômico é fundamental já que se prende à satisfarão de necessidades e motivos biológicos fundamentais do ser humano. Todavia, é preciso observar e reconhecer que o homem também tem outras necessidades fundamentais, não orgânicas e sim espirituais, como o desejo de conhecer, de aprender, de amar, e ser amado, de apreciar a beleza e de fazer o bem. Ora, ciência, ternura, caridade não se reduzem ao exercício dos sentidos a à atividade das glândulas, e assim como as necessidades orgânicas constituem o princípio determinante da infra-estrutura econômica da sociedade, assim também as necessidades intelectuais e morais constituem o princípio da infra-estrutura espiritual. Sim, é isso mesmo, o espírito é tão infra-estrutural quanto o corpo. Em conseqüência, se para certos fenômenos culturais, os econômicos, existe uma causalidade biológica, para outros, mesmo econômicos (lembre-se a proibição da usura na Idade-Média) existe uma causalidade espiritual e seria grave engano confundir os dois tipos de causalidade e atribuir ao fator econômico uma causalidade que, em muitos casos, dêle não depende em princípio. Quando a verdadeira causa de um fenômeno ou situação for espiritual, o fator econômico pode estar presente, mas não como causa e sim como condição, acidental ou essencial, contingente ou necessária. As necessidades espirituais são distintas das orgânicas, embora a satisfação destas possa realmente condicionar a satisfação daquelas. A causa da intelecção, da compreensão de um problema, de uma sentença é o meu poder intelectual, manifestando-se através de suas operações: a abstração, o juízo, a comparação, o raciocínio, a reflexão. Não estarei, porém, inteiramente dono dêsse poder, se não dispuser de bom estado corpóreo, saúde, saciedade, repouso; se não puder desenvolver êsse poder através de situações de vida que me proporcionem lazer para a leitura, o estudo, a reflexão:

Platão já divisara com muita acuidade essa distinção capital. Quando se fala em causa, pensa-se sobretudo na causa eficiente, isto é, naquilo que produz alguma coisa, como o pintor é causa de seus quadros, como eu sou o autor destas linhas. Mas o pintor não po-

nômica é a base, mas que os diversos elementos da superestrutura atuam no curso das Iutas historicas, e em muitos casos, determinam-Ihes a forma de maneira preponderante. Nós mesmos fazemos a história em condiçōes bem determinadas. Entre toutes, ce sont les conditions économiques qui sont finallement déterminantes. Karl Marx-Friedrich Engels, Etudes Philosophiques, Paris, Editions Sociales, 1951, 173 págs. Cf. pág. 128. Demais disso: Engels, Lettre à Hans Starkenburg (Londres, 25 Janvier 1894) in Ludwig Feuerbach et la fin de la Philosophie Classique Allemanae. trad. Bracke, Paris, Alfred Costes, 1952. 
deria pintar se ñão dispusesse não só de outras causas: a tinta, o pincel, como também de condições necessárias: os recursos para a aquisição da tinta e do pincel, a tela, o cavalete ou a parede, a claridade, etc. Eu não poderia estar a escrever êste trabalho se não contasse, não apenas com outras causas como as palavras, a caneta, a intenção de cumprir com uma obrigação, mas também com certos requisitos como a disposição para escrever, à mesa, a luz, etc. Ora, Platão percebeu e exprimiu notàvelmente a distinção entre causa e condição, ainda que em grego use de um circunlóquio para definir esta última:

"Porém é mais do que absurdo dar a tudo isso o nome de causa (diz Sócrates, desiludido com a explicação que esperara encontrar nas obras de Anaxágoras). Se alguém dissesse que sem os ossos e os músculos e tudo o mais que tenho no corpo não me será possivel fazer o que me aprouver, só dirá a verdade. Mas, afirmar que é por (causa de) tudo isso que eu faço. o que faço e que, assim procedendo, atuo com auxílio da razão, sem, contudo, decidir-me pelo melhor: isso é que seria mais do que brincar com as palavras. Trata-se de uma distinção que nem todos são capazes de fazer: que em tudo, uma coisa é a causa pròpriamente dita, e outra (muito diferente) aquilo sem o que a causa não poderia ser causa. A meu pensar, parecem tatear no escuro os que, recorrendo à expressão imprópria, dão a isso o nome de causa" (19).

Tudo o que antecede permite-me agora afiançar que o progresso, da agricultura, o desenvolvimento do comércio e a ressurreição das cidades na França do século XII, assim como outros eventos já referidos anteriormente, foram condições necessárias para o aparecimento da Universidade de Paris, mas não as suas causas.

\section{VI}

Duby (20) intitula a época que se estende de 1070 a 1180 de "o século do grande progresso". Os moinhos, que já existiam, tornam-se mais numerosos. As mós para produzir farinha tornam-se acessíveis a tôdas as famílias camponesas. O abandono do pilão e da moagem manual acarreta "uma notável libertação da mão-de-obra", assim como "uma revolução alimentar", pois às pastas de cereais e ao milho sucedem o pão e o trigo. Com o uso mais frequiente do ferro, desde 1050, aperfeiçoam-se os instrumentos agrícolas, divulga-se o grande machado de corte e a charrua de relha. Com o ferro surge

(19). - Platăo, Fedão, 99 b.

(20). - Este parágrafo basela-se no capítulo terceiro da obra: G. Duby-R. Mandrou, Histoire de la Civilisation Française. Moyen-Age - XVI siècle. Paris, Armand Colin, 1958, 360 págs. 
nas aldeias o único operário especializado dêsses tempos: o ferreiro. A agricultura progride com o melhor arranjo da rotação das culturas. As queimadas e rotações desordenadas são substituídas pelo ciclo em ritmo ternário:

- semeadura de farinhas do inverno: trigo ou centeio;

- semeadura de cereais da primavera: aveia ou cevada;

- descanso do alqueive.

Essa renovação agrícola é notável, embora imperfeita e limitada no espaço (ao Norte principalmente) e no alcance: o equipamento é caro. O camponês agora dispõe de mais alimento em menos tempo e com menos esfôrço. Consequiências diretas da alimentação mais segura e abundante são o aumento da população e a libertação da mãode-obra para outros empreendimentos, em virtude do aumento das rendas e da diminuição das corvéias senhoriais. Apesar de variações na produção de víveres, conforme as oscilações climatéricas, o fato é que, desde 1050, mais ou menos, desaparecem aquelas terríveis e periódicas epidemias de fome que haviam assolado a França anteriormente. O modo de vida dos campônios, afora essa segurança alimentar, continuou o mesmo. Tal não ocorreu, entretanto, no mundo dos senhores, clérigos ou nobres, que se transformou ràpidamente. Os rendimentos dos senhores vieram permitir um alargamento da "côrte", ou seja, aumento do pessoal e a possibilidade de arcarem com maior número de hóspedes, a multiplicação de viagens e visitas. A animação das estradas, por sua vez, fomentou as trocas comerciais, despertadas e facilitadas pelos últimos acontecimentos políticos (as Cruzadas, o estabelecimento de um reino franco na Síria, a atividade comercial das cidades italianas). Os nobres habituaram-se a consumir mercadorias de luxo e surge um nôvo tipo profissional, o comerciante, cuja atividade vai tornar a moeda mais abundante e cujo gênero de vida vai reanimar e desenvolver as cidades. Daí, levarem seus interêsses à organização das comunas contra os abusos dos senhores, à reivindicação das liberdades para o burgo e, por fim, à constituição de uma nova classe, a burguesia.

\section{VII}

Até o ano de 1100 a França, como outros países ocidentais da época, é um conjunto de principados, dentre os quais o domínio real avulta pelo título, pela fôrça da tradição. Mas no plano da riqueza e do poder, da influência e do prestígio, é muitas vêzes, um senhor, um duque, que sobreleva. Se o latim é a língua em que todos os europeus se entendem, em cada domínio francês fala-se um dialeto: o normando, o picardo, o provençal, etc. Em 1300 a França constitui uma 
monarquia. Os Capetos souberam impôr-se aos barões pela fôrça e pela habilidade; da Ile de France alargaram progressivamente seus domínios até integrarem o Midi ao Norte. O centro catalizador de energias de tôda a França é Paris, que se torna não só a capital política, como também a capital das letras, das artes, do pensamento, das escolas, atraindo estudantes e professôres, homens de aptidões diversas, da Europa inteira (21) .

Como observa Génicot (22), ao unificarem sua terra, os Capetos the pouparam as lutas internas que se desencadearam na Alemanha e na Itália sob Henrique IV, assim como as crises políticas pelas quais passou a Inglaterra desde a morte de Guilherme, o Conquistador até a chegada de Eduardo I. Além disso, a França escapou às querelas entre o Papado e o Império, que ocorreram nos domínios germânicos e não apresentou conflitos como os que estalaram entre os Plantagenetas e a Igreja da Inglaterra conduzida por São Tomás Beckett ou por Estêvão Langhton. Paris tornou-se uma cidade cosmopolita durante o século XII. Em suas ruas acotovelavam-se estudantes de várias regiões da Europa, viajantes e peregrinos, que depois retornariam a seus pagos a celebrar-lhe a fama. Papas, cardeais, bispos, diplomatas, sábios, nobres, monges e negociantes passavam em Paris os anos de sua formação ou de aperfeiçoamento na idade adulta. O título de Cidade-Luz já cabia, com razão, a Paris desde o século XII.

\section{VIII}

Para Maurice De Wulf o século XII é o período primaveril em que a civilização medieval assume seus contornos definidos. Eu diria a época em que se configuram cristalinamente as constelações do "Cosmos da Idade Média", para empregarmos a expressão usada por Wolfram von den Steinen (23). A observação de De Wulf é assaz importante, pois é muito comum ver-se a denominação medieval estendida univocamente a aspectos da vida dos séculos VII, VIII, XI e XV. Ora, se todos os séculos compreendidos entre o ano 500 e o de 1500 compõem a Idade Média, o têrmo medieval, significando

\footnotetext{
(21). - Veja-se a descrição retórica de Paris numa carta de Gui de Bazoches (1175-1190) que, sem se referir às escolas, alude às artes liberals: "In hac insula perpetuam sibi manstonem septem pepigere sorores, artes videlicet liberales". Chartularium, I, introd., no 54, apud Rashdall, ob. cit., vol. I, pág. 277, note 3 .

(22). - Léopold Génicot, Les lignes de faîte du Moyen-Åge, troislème édition revue, Tourna1 (Belgique), Casterman, 1961, 377 págs. Cr. pág. 196.

(23). - Wolfram von den Steinen, Der Kosmos des Mittelalters von Karl dem Grossen zu Bernhard von Clairvaux, Francke Verlag Bern und München, 1959, 400 págs.
} 
certa maneira de pensar, de sentir, de agir, mentalidade e instituições, não pode ser sempre aplicado com o mesmo alcance a todos os momentos do período. Walsh concebe um humanismo medieval em que se integram elementos como a fôrça dos germanos, a imaginação dos celtas, a sabedoria grega, a experiência de vida, o senso de organização dos romanos e a Graça Evangélica, que veio do Oriente. Esses elementos se juntam e confundem durante os séculos da Alta Idade Média. Por isso diz de Wulf que antes do século XI o temperamento medieval ainda não estava formado, mas apenas em processo de elaboração. Eu preferiria dizer, em lugar de temperamento, que a "personalidade básica" do homem medieval só se constitui definitivamente durante o século XII. A personalidade básica é um nôvo conceito sociológico que se presta excelentemente à aplicações históricas como a que acaba de ser mencionada. A personalidade básica é, além do eu individual, a atmosfera cultural em que êste imerge, atmosfera constituída pelas instituições primárias e secundárias (24) e que aproxima a singularidade dos membros de um grupo com um traço de união cultural.

Durante os primeiros tempos da Idade Média, as novas raças, celtas e teutões, como diz De Wulf (celtas e germanos prefiro dizer) receberam passivamente elementos culturais, jurídicos e políticos de procedência greco-romana. A partir do século IX, êsses povos reagem a tudo quanto lhes foi proposto, e tudo assimilam à sua maneira, sob a orientação da Igreja. O século da conformação das feições institucionais e culturais é o século XII. O século seguinte será a época da maturidade e do esplendor da civilização.

Durante o século XII, a França marcha para a centralização monárquica que será o princípio do absolutismo. Desenvolvem-se, progridem as artes e os negócios. Crescem as cidades, aumenta a rique$\mathrm{za}$, montam-se estabelecimentos de crédito, a arquitetura romana atinge seu clímax, surge o estilo gótico. As literaturas vernáculas aparecem nos romances inventados pelos trovadores, as Canções de Gesta, desde o século anterior juntamente com o teatro religioso e o lirismo provençal. 1050-1150, "Século das Gêneses", como tão bem o denominou Gustave Cohen (25), logo seguido pela floração mineral das catedrais e pela entrada em cena do amor cortês e do culto à mulher. As cartas de Abelardo e Heloísa testemunham a fôrça imortal do amor humano, como os hinos de São Bernardo e as estâncias de Adão de São Vítor, as inspirações sublimes do amor di-

\footnotetext{
(24). - Sôbre personaliaade básica: Bibliothèque de Soclologie Contemporaine, Mikel Dufrenne, La Personnalité de Base, Um concept sociologique, Paris, P.U.F., 1953, 345 págs.

(25) . - Gustave Cohen, La Grande Clarté du Moyen-Âge, Paris, Gallimard, Quatorzième Édition, 1945, 181 págs., cf. pág. 29.
} 
vino (26). A instituição da cavalaria evolui e apresenta no século XII uma face completamente cristã, que será idealizada nas páginas da Nova Milícia de São Bernardo e logo mais no livro da Ordem de Cavalaria de Raimundo Lúlio. O caráter religioso da Cavalaria foi o resultado das Instituições de Paz, a "Trégua e Paz de Deus", iniciativa da Igreja para assegurar proteção aos fracos, ao clero, aos campônios contra a prepotência e o absolutismo do barão feudal (27). Mas, sobretudo, nova observação profunda feita por De Wulf (28), é neste tempo que se plasma e afeiçoa o nôvo espírito vivificador desta personalidade básica do homem medieval, o sentimento feudal por excelência, de que a nossa consciência moderna ainda está tão profundamente imbuída: o sentimento do valor e da dignidade do homem individual. Isso não é apenas uma conseqüência do estilo senhorial. da vida, uma decorrência da lealdade feudal, mas também um fruto da influência cristã sôbre os costumes e a mentalidade dos bárbaros. Numa carta de Pedro, o Venerável, uma das grandes figuras do século XII, a São Bernardo, em que o primeiro rebate acusações contra sua ordem que êste levantara, podemos registrar o reconhecimento corrente da dignidade dos servos, não mais os escravos da Antigüidade: "Servos e servas não como servos e servas são tidos e tratados, mas como irmãos e irmãs". Os monges, continua Pedro, o Venerável, utilizam os serviços dos camponêses, mas não os aborrecem com exações nem lhes impõem algo de insuportável. Pelo contrário, em suas necessidades assistem-nos com os recursos do mosteiro (29). Como

(26) . - Sôbre Adão de Sáo Vitor e sua poesla consulte-se: Henry Adams, MontSaint-Michel et Chartres, Clefs du moyen-age français, traduit de l'anglais par Georges Fradier et Jacques Brosse, Paris, Robert Laffont, 1955, 385 págs.

(27). - Hefele-Leclercq, Histoire des Conciles d'après les dccuments originaux, $t$. V-1, Paris, Letouzey, et Ané, Editeurs, 1913. Cf. Décimo Concillo Ecumênico (29 de. Latrão). O cânon 11 prescreve que os monges, os clérigos, os estrangeiros, os comerciantes e os camponeses devem estar sempre em segurança, isto é, gozar da trégua de Deus. O cânon 12 indica as penalidacies aos que a transgredirem e faz enérgica recomendaçáo aos bispos para a manutenção da paz. Delaruelle, ob. cit., págs. 234-237.

(28). - Louis Clark Vanuxem Foundation, Maurice De Wulf, Philosophy and Civilization in the middle ages, New York, Dover Publications, Inc., 1953, 312 págs., cap. two.

(29) . - "Servos et anclllas, non ut servos et ancllas, sed ut fratres et sorores habent, discretaque ab eis pro possibilitate obsequia susciplentes, ninll gravaminis eos incurrere patiuntur; slcque secundum apostolicum praeceptum: tanquam nihil habentes, et omnia possidentes existunt (I Cor., VI) . Pedro, o Venerável, a São Bernardo, abade de Claraval, P. L. (Mig-ne), t. 189 , ep. XXVIII, cl. 146 B. Demais disso: "Monachi vero, tametsi haec habeant (servos e servas), non tamen similiter, sed multum dissimiliter habent. Rusticorum namque legitimis et debitis solummodo servitis ad vitae subsidia utuntur, nullis exactionibus eos vexant, ninil importabile imponunt; si eos egere viderint, etiam de propris sustentant" cl. 146 D. - Delaruelle, ob. cit., pág. 267, Role soctal et problèmes économiques (de Cluny). 
nota Delaruelle (30), examinando o papel social de Cluny, "muitas vêzes os objetos litúrgicos foram vendidos para alimentar os pobres e a libertação dos servos foi praticada constantemente".

O século XII é a época em que surge a Universidade de Paris, uma corporação de professôres e estudantes irmanados pelo amor à sabedoria no entusiasmo pelos estudos.

\section{IX}

A Universidade de Paris não surgiu repentinamente, não foi o resultado de uma decisão pontifícia ou monárquica, não se originou de um plano bem arquitetado nem se inspirou em instituições préexistentes. Tal como a Universidade de Bolonha, ela veio surgindo, durante o século XII, condicionada por muitos acontecimentos e determinada por múltiplos fatôres. Assim, pois, se percebe a fantasia de que se reveste a tese de Ribera y Tarragó (31) que apontava as escolas árabes como o modêlo que presidiu à fundação das Universidades ocidentais. Essa tese não dispõe, afora certas analogias, de base histórica alguma e só pode ser pensada devido às semelhanças estruturais de uma certa constante cultural. Desde que o homem atingiu um certo grau de desenvolvimento intelectual, desde as primeiras civilizações do Oriente, já se pode divisar a estratificação de níveis de ensino tendo o superior por cúpula, como os colégios sacerdotais do Egito, as escolas dos brâmanes, as escolas de Atenas, Alexandria, etc. Nada de estranho que as escolas superiores tenham existido também entre os muçulmanos na Ãsia, África e Espanha, já que a conquista maometana levara os árabes ao domínio de velhos centros culturais no Egito, na Pérsia, na Síria e os pusera em contacto direto com a cultura grega através de mestres cristãos do Oriente.

A Universidade medieval do Ocidente tem feição própria, organizaçã́o típica, e caracteriza-se, em Paris, pela sua formação espontânea durante o século XII. Não há documento, não há prova, não há vestígio que permita adiantar a hipótese de Ribeira y Tarragó. Os antigos como os egípcios, os indus, os gregos, os romanos, os persas ou muçulmanos medievais tiveram escolas superiores, mas não universidades. Estas foram criações da Idade Média Ocidental, como o Parlamento e a Catedral (32).

(30). - Delaruelle, ob. cit., pág. 267.

(31). - A tese de Ribera y Tarragó é menclonada em: Alfredo Guilherme, Filosofia e Teologia in Untversidad de Oxford, El legado del Islam, editado bajo la dírección de Sir Tomas Arnold y Alfred Guillaume, traducido del inglés por Enrique de Tapla, segunća edición revisada por P. Blanco Suárez, Madrid, Ediciones Pegaso, 1947, 519 págs., cf. págs. 313-369; Maria Angeles Galino, Historia de la Educación - I Edades Antigua y Media, Madrid, Editorial Gredos, 1960, 596 págs., cf. pág. 462.

(32). - Hasktns, The rise of universities, Ithaca, New York, Great Seal Books, A Division of Cornell University Press, 1957, 107 págs., cf. pág. 1. 
Stephen d'Irsay usa da linguagem aristotélica "tão cara à Idade Média", para encontrar uma fórmula, a fim de compreender a formação das universidades. Estas teriam sido determinadas por quatro causas, a saber: a material, a formal, a eficiente e a final. A causa material foi o magnífico crescimento do saber humano durante o século XII; a causa formal, o desenvolvimento das corporações; a causa eficiente, um acontecimento fortuito, como a iniciativa de um Papa, de um rei, de um príncipe; a causa final, a atração das grandes carreiras indispensáveis à sociedade, ao serviço de Deus e da Igreja .

Denifle refere-se aos fatôres que concorreram para a formação das Universidades. Para êle não se pode explicar a origem da Universidade de Paris ou de Bolonha apenas pela aglomeração de alunos em tôrno de um professor famoso. Nenhum dêstes, desde o século $X$, logrou estabelecer escola permanente. A tal fato, há que acrescentar outros fatôres decisivos para o aparecimento da Universidade: "o novo método de ensino" constituído pela aplicação da dialética às doutrinas religiosas, pela organização de novos procesos didáticos (lectio, glosa, quaestio, etc.) e pela redação das Sumas, tudo obra do século XII: "os Privilégios" com que reis, como Luís VII e Filipe Augusto, e papas como, Inocêncio III, galardoaram o studium parisiense; por fim, a formação, durante o século XII, das "Corporações". Antes disso só havia escolas superiores em Paris e Bolonha. O caráter corporativo que elas vão assumir, ein wesentlicher Factor, é que as determinará como Universidades (33).

Percebe-se meridianamente que as causas intrínsecas da instituição universitária, a material e a formal (34) conferem com os fatôres aludidos pelo dominicano alemão: o aumento do saber, incluindo o desenvolvimento das escolas e dos métodos, e o surto do movimento corporativo com os privilégios obtidos pela corporação de professôres e estudantes.

Arrowood menciona as condições highly conducive para o estudo das artes e ciências liberais e das disciplinas profissionais (35) e as essential conditions para a origem das Universidades, fornecidas pela atuação das instituições escolares dos séculos XII e XIII, indicação correta no que tange às condições, mas imprecisa em relação aos determinantes causais da universidade.

Conjugando Denifle com Stephen d'Irsay, diremos que o aparecimento da Universidade de Paris deveu-se a fatôres causais básicos, tal como o crescimento do saber, acompanhado pelo desenvolvimento (33). - Denifle, ob. cit., págs. 40-63.

(34). - As causas intrínsecas são a material e a formal, que constituem o próprio ser da coisa, por exemplo, o bronze (matéria), e a flgura do Duque de Caxias (a forma) numa estátua. A causa eficiente e a causa final são as causas extrinsecas, que concorrem para produzir o ser "ab extra".

(35). - Eby-Arrowood, ob. cit., chap. 17. Cf. pågs. 756 e 758. 
das escolas urbanas episcopais (36) e a formação do movimento corporativo que informa a aglomeração de mestres e estudantes, a princípio espontâneamente e em seguida jurìdicamente, afeiçoando, desde o século XIII, a Universidade, instituição típica da cultura ocidental.

O têrmo Universidade (universitas) designava entre os romanos um colégio, uma associação com qualquer fim (37). Na Idade Média o têrmo se aplica simplesmente a um conjunto de pessoas, como no início de uma carta universitas vestra significa "a todos vós" ou a uma pessoa jurídica como a universitas mercatorum, corporação dos comerciantes. Depois o têrmo se especializa para designar a corporação dos mestres e dos alunos das escolas de Paris, que eram autenticos "trabalhadores" intelectuais, como trabalhadores eram os membros das outras corporações (38). Refere Bride que, no século XIV, Pedro d'Ailly e Gerson tentaram ligar a Universidade de Paris às escolas dos egípcios, enquanto Simão de Cramaud fazia-a remontar às escolas de Atenas. O mito que atribui a fundação da Universidade de Paris a Carlos Magno, diz Rashdall, já nem é mencionado pelos historiadores sérios, até mesmo com o objetivo de refutá-lo (39). A propósito dessas genealogias da Universidade de Paris, vale a observação perpicaz de Bride de que há uma verdade subjacente "sous ce fatras de fantaisie". Desfeitas as superestruturas das escolas helenísticas de Pérgamo, Edessa, Antioquia, Atenas, Alexandria, das escolas imperiais de Roma, da Gália ou da África, restaram e persistiram as bases que forneceram os materiais para a renovação da cultura: as artes liberais.

\section{$*$

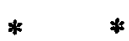 \\ CAPITULO II \\ O CRESCIMENTO DO SABER}

A expressão Artes Liberais foi cunhada pelos Romanos e foi um romano, Varrão, quem as classificou definitivamente em seus

\footnotetext{
(36). - Rashđall, ob. cit., pág. 275: "The University was an outgrowth of the Cathedral School of Paris...".

(37). - Bride (A.), Universités, in "Dictionnalre de Théologie Catholique", Vacant-Mangenot, T. XV, Tre partie, cl, 2230-2268. Cf. cl. 2230.

(38). - A respeito dos mestres e estudantes da Universidade como trabalhado:e intelectuais ver Jacques Le Goff, Les intellectuels au Moyen-Age, "Ed1tíons du Seuil", Paris, 1957, 191 págs.

(39) . - Rashdall, ob. cit., pág. 271.
} 
Disciplinarum Libri IX, a primeira enciclopédia (1) . Contudo, a matéria significada pelas artes liberais procede de época mais antiga.

$\mathrm{Na}$ India havia dez ciências auxiliares que preparavam o brâmane para o estudo dos Vedas, entre as quais a fonética, a gramática, a exegese, a lógica, a astronomia, a metrologia (2). Entre os egípcios estudavam-se, em nível elementar, as letras com a gramática, a aritmética, a geometria, a música e a astronomia, que preparavam o aluno para o estudo superior das ciências nos colégios sacerdotais (3). Na Grécia, o ensino elementar abrangia o estudo da gramática, a leitura dos poetas, noções de cálculo, música, geometria e astronomia, iniciação ao estudo mais aprofundado dessas disciplinas e da filosofia nas escolas superiores. No período helenístico, o ensino das artes assume feição rigorosamente curricular com o círculo da educação ou das ciências.

Para Filão de Alexandria o ensino inferior compreendia o estudo das artes como a gramática, a retórica, a geometria, a música e a astronomia, "a rainha das ciências" (4). Varrão, pouco antes do início da éra cristã, fixa o elenco das artes liberais da seguinte maneira: gramática, dialética, retórica, geometria, aritmética, astrologia, música, medicina, arquitetura. As três primeiras eram lecionadas nas escolas romanas e as outras nas escolas da Grécia. Vitrúvio, em seu tratado sôbre arquitetura (5), encarece a necessidade do estudo das letras, do desenho, da geometria, da história, da filosofia, da música, da medicina, do direito e da astrologia, para o aprendiz de arquiteto. Cícero enumera como matérias propedêuticas ao estudo da Retórica: geometria, música, literatura, poesia, física, ética, política. Quintiliano em sua Institutio Oratoria examina a formação do orador através da Gramática e da Retórica, referindo-se à educação geral que as crianças devem receber antes de serem confiadas aos Retóricos e destacando o valor formativo de disciplinas como a música e a geometria.

(1). - R.-Martin, Arts Libéraux (Sept) in Dictionnaire a'Histoire et ae Géographie Ecclésiastiques, Faris, Librairie Letouzey et Ané, 1930, T. I. Cl. 827-843.

(2) - Para uma idéia descas matérlas estudadas na india. Cf. Blbliothèque Historique, Louis Renou, Anthologie Sanskrite, Textes de l'Inde Ancienne traduits du sanskrit, Paris, Payot, 1947, 406 págs.

(3). - Consejo Superior de Investigaciones Clentificas - Instituto "San José de Calasanz" de Pedagogía. Série B. - Número 3, Otto Willmann, Teoría de la formación humana, tradución del alemán por Salustiano Duñaturria, tomo I, pág. 141,2 vols. Madrid, sem data.

(4). - The Loeb Classical Library, Philo, with an English Translation by F. $\mathbf{F}$. Colson, M. A. and the Fev. G. H. Whitaker, M. A. In eleven volumes IV - On mating with the preliminary studies, págs. 458-551, London, William Helnemann Ltd., 1949, 582 págs.

(5). - The Loeb Classical Library, Vitruvius, On architecture, Translated into english by Frank Granger in Two Volumes - I - London, Wtlliam Helnemann Itd., 1955, 322 págs. - Livro I, c. I. 
Santo Agostinho iniciou em Milão uma Enciclopédia das Sete Artes Liberais, da qual só restou o tratado sôbre a música (6). Por volta de 420 a. C., Marciano Capella redigiu em Cartago os Satyricon Libri IX cuja famosa introdução descreve, em dois livros, as núpcias de Mercúrio com a Filologia e que foi obra de tanta repercussão durante a Idade Média. Os outros sete livros são dedicados às sete artes liberais conforme a classificação de Varrão. Boécio, por sua vez, inspirando-se em fontes gregas, compôs tratados de aritmética, música, geometria, dialética, retórica, além de traduzir e comentar obras de Aristóteles, Cícero e Porfírio. Juntamente com Boécio e Marciano Capella, Cassiodoro contribuiu para a transmissão do saber antigo à idade medieval incipiente (7). Suas Institutiones saecularium lectionum resumem em sete capítulos as obras latinas anteriores. As disciplinas liberais (liberales litterae) são apresentadas na ordem formulada por Varrão. O curioso neste resumo de Cassiodoro é que para os antigos o têrmo liberal derivava de liber (livre), donde as artes liberais serem estudo reservado aos homens livres, enquanto para êle liberal, livre, deriva de livro (liber autem dictus est a libro), isto é, da casca da árvore, cortada e liberada e na qual os antigos redigiam seus poemas (8). Santo Isidoro de Sevilha, baseando-se apenas nos autores latinos, consagra os três primeiros livros de suas Etimologias às artes liberais: os dois primeiros às três primeiras artes $\mathrm{e}$ o terceiro às artes matemáticas (9). São Beda e Alcuíno consagraram monografias a quase tôdas as artes liberais. Estas dividiam-se em dois grupos desde Boécio, mas foi Alcuíno quem apresentou um programa de ensino, no século IX, constando do Trivium e do Quadrivium. O Trivium abrangia a gramática, a dialética, a retórica, matérias que tinham por objeto a linguagem, o discurso e por isso fo-

\footnotetext{
(6). - Henri-Irénée Marrou, Saint Augustin et la fin de la culture antique, E. De Boccard, Editeur, Paris, 1949, 620 págs. Sôbre as artes liberais veja se o cap. III da 2.a parte, pág. 211 e a respeito de Santo Agostinho e as artes liberais, cf. o cap. IV da mesma parte, pág. 237.

(7). - Mote-se o simbolismo do ano 529 d. C. para a Idade Médla inciplente. Hegel em suas liçōes de História da Filosofia assinala a data de 529 que corresponde "à ruína dos estabelecimentos exteriores da filosofia pagE"; mas, diz Pieper, "cette même année vit aussi un autre événement, que Hegel passe sous silence: la fondation par saint Benoit du cloitre du Mont Cassin; en cette année-limite de 529, au moment même où s'écroule un monde épuisé, c'est bien un nouvelle époque que signifie parellle fondation". Joseph Pleper, Actualité de la scolastique (traduit par Maurice de Gandillac), La Table Ronde, n.8 166 - novembre 1961, pág. 21.

(8). - Cassiodori Senatoris Institutiones, Edited from the Manuscripts by $\mathbf{R}$. A. B., Mynors, Oxford, At the Clarendon Press, 1961, 193 págs. Lib. II, praef., pág. 91; PL 70 .

(9) - - San Isidoro de Sevilla, Etimologias, versión castellana de don Luís Cortés y Góngora, Madrid, Biblioteca de Autores Cristianos, 1951, 563 págs.; PL 82, cl. 73-728.
} 
ram chamadas, durante a Idade Média, de artes sermocinales. O Quadrivium ou Matemática compreendia a aritmética, a geometria, a astronomia e a música (teórica), disciplinas aplicáveis às quatro espécies de coisas reais, res: o número, o espaço, a esfera celeste, a harmonia. Denominavam-se artes reales ou physicae. Em suma, Trivium e Quadrivium eram cursos de letras e ciências.

\section{II}

Durante o século IX pulularam obras sôbre a gramática, adaptações e comentários sôbre as sete artes. E' a época de Loup de Ferrières, Escoto Eriúgena, Heiric e Remi de Auxerre. Tempo de lutas internas e das invasões normandas. Na segunda metade do século $\mathrm{X}$, com a normalização da vida ocasionada pelo cessamento das invasões, o panorama cultural se transforma completamente. Lobbes, Liège, Reims destacam-se no estudo das ciências exatas. Herigério em Lobbes e Gerberto d'Aurillac (o futuro Papa Silvestre II) em Reims, brilham por seus estudos matemáticos. Herigério inventou um nôvo ábaco, errôneamente atribuído a Gerberto, que veio substituir o ábaco romano nas escolas monásticas e nas escolas episcopais. Gerberto estudou matemática na Espanha e foi um dos agentes da introdução da ciência árabe nas escolas ocidentais. Foi então que surgiram nas escolas os algarismos arábicos, datando daí a luta entre Abacistas, que preferiam o cálculo pelo ábaco e os Algoristas que calculavam com a pena à luz da aritmética dos árabes (10). A partir do século IX, em meio de conflitos teológicos, desde Scoto Erígena passando por Berengário de Tours, Anselmo de Besate, Gerberto d'Aurillac, Fulberto de Chartres, Lanfranco e Santo Anselmo de Bec até chegar a Abelardo, a Dialética forceja por escapar ao guante teológico para constituir-se como ciência autônoma. Quando se lêem os textos de dialética, desde Santo Agostinho até Abelardo, nota-se que os autores sempre lhe apontam o objetivo único de servir à defesa das verdades religiosas. Essa autonomia da Dialética vem a ser fomentada através da introdução progressiva do Organon, desde o século IX, no ensino escolar e nas obras teológicas. Durante o século XII, o estudo da dialética recebe impulso decisivo com a introdução da Lógica Nova, isto é, os restantes tratados lógicos de Aristóteles até então desconhecidos. O estudo da dialética equivale ao estudo da filosofia pròpriamente dita que, no século XII, começa a fazer estalarem os quadros tradicionais das sete artes liberais num processo que irá culminar com as transformações da Faculdade de Artes em Faculdade de Filosofia no século XIII, após a introdução maciça das

(10). - Cf. Martin, Arts Libéraux, iđem, nota 1. 
obras de Aristóteles no ensino universitário. Abelardo, Gilberto de la Porrée, Roberto de Melun servem-se da dialética para transformar o estudo da Sacra Pagina, que se resumia na contemplação das verdades dogmáticas através da leitura e da meditação da Bíblia, em especulação religiosa que inaugura o nôvo estilo teológico, o escolástico, cujo máximo representante será Santo Tomás de Aquino.

c A escola de Chartres, desde Gerberto, com Adelardo de Bath, Thierry de Chartres, Guilherme de Conches, Alain de Lille, desempenhou um papel de capital importância na renovação cultural do tempo, com a introdução e a vulgarização no Ocidente das obras astronômicas traduzidas do árabe.

\section{III}

No tocante ao conceito das Artes Liberais no século XII, destacam-se, entre outras, as obras de Hugo de São Vitor, João de Salisbury, Conrado de Hirschau e de uma mulher, a monja Herrad de Landsberg, abadessa de Hohenburgo na Alsácia. A obra desta última, o "Jardim das Delícias" (Hortus Deliciarum), principiada em 1167, é uma compilação enciclopédica para o ensino das monjas, cônegas da Ordem regular de Santo Agostinho. E' obra de leitura agradável com poesias intercaladas no texto, muitas com acompanhamento musical e numerosas ilustráções referentes à história bíblica e a assuntos teológicos (11). Nessas ilustrações as Artes são representadas como rios que dimanam da Filosofia, ainda que se acrescente: "O Espírito Santo foi o inventor das Sete Artes Liberais".

Conrado de Hirschau (1070-1150) em seu Dialogus super auctores sive Didascalion exorta seu discípulo:

"Quem filosofa em Cristo sempre é instruido nas artes liberais, e, vencedor dos vícios, ganha a liberdade dos filhos de Deus; puis de nada te serviria ultrapassar os outros nas sete disciplinas se, continuando a cultivar os vícios, te submetesses à pior escravidão" (12) .

(11) - Otto Wilmann, Teoria de la formación humana, iđem, nota 3, pág. 266. Veja-se também a observação à pág. 256 a propósito das artes liberais: "outro modo de designá-las é sapientia Hybernica ou methodus $H$. que lembra a função de transmissores desempenhada pelos monges irlandeses nos estudos da primeira Idade Média". A respeito da monja Herrad veja-se Manitius, Geschichte der lateinischen Literatur des Mittelalters, Dritter Teil, München, C. H. Beck'sche Verlagsbuchhandlung, 1931, 1164 págs. - Cf. pág. 1010-1014. Manitius apresenta a grafia Herrat von Landsberg, assim como em vez de Conrado von Hirsau (cf. nota 12), escreve von Hirschau, pág. 315.

(12). - Conrado de Hirsau (1070-1150), Dialogus super auctores sive didascalion apud Eugenio Garin, Geschichte und Dokumente der abendlädiisch en, Pädagogik I - Mittelalter, Rowothus deutsche Enzyklopädie, Hamburg, burg, 1964, 301 págs. - IX. Konrad von Hirsau, págs. 143-1.59. 
João de Salisbury, o fino humanista do século XII, escreveu o Metalogicon, a fim de defender o valor do Trivium contra os ataques desfechados pelos Cornificianos, que menosprezavam o estudo acurado das artes sermocinais. A arte, diz Salisbury (13), é um recurso inventado pela razão, a fim de apressar, por expedientes próprios, o desenvolvimento de nossas habilidades para fazer bem as coisas. Equivale ao que os gregos chamavam de método, ou seja, um plano eficaz para ordenar e dirigir o curso da natureza, de tal modo que se possa realizar correta e fàcilmente o que se está a fazer. A natureza é a mãe de tôdas as artes às quais ela deu a razão por guia. Ela providenciou de antemão os três fatôres básicos, instrumentos de tôdas as artes: capacidade natural, memória e razão. A primeira é desenvolvida por meio do estudo e do exercício. Salisbury examina em seguida a razão pela qual certas artes são chamadas liberais (14). Entre as várias espécies de artes, são elas que por primeiro prestam serviço às capacidades naturais de quem estuda. Estão contidas no Trivium e no Quadrivium. Chamam-se liberais, seja porque os antigos cuidavam de nelas instruir seus filhos (liberos), seja porque seu objetivo é a libertação (libertatem) do homem, de tal forma que, livre dos cuidados incompatíveis com a sabedoria, como as inquietações acêrca das necessidades materiais, possa o espírito aplicar-se com mais liberdade à filosofia.

Hugo de São Vítor redigiu o melhor manual da época para iniciação no estudo das artes liberais: o Didascalicon, que se pode traduzir por "o Manual". Chega-se ao domínio do conhecimento (quisque ad scientiam instruitur), nota o prefácio, através da leitura e da meditação. No ensino a primazia cabe à leitura (lectio, estudo dos textos) e êste livro the é consagrado, fornecendo regras para o estudo (dando praecepta legendi). No fim do 10 livro do Didascalicon Hugo resume-lhe o conteúdo, aludindo aos quatro ramos do conhecimento: o teórico visa à contemplação da verdade; o prático considera a ordem moral; o mecânico provê às ocupações desta vida; o lógico proporciona o conhecimento necessário para a linguagem correta $\mathrm{e}$ para a argumentação clara. Estes quatro ramos do conhecimento, ou artes, tendem para o único fim da sabedoria, que é arte das artes e a disciplina das disciplinas. Daí a divisão da filosofia em quatro partes (Livro II): a teórica, a prática, a mecânica e a lógica. As matérias do quadrívio tradicional integram a filosofia teórica, enquanto as disciplinas do trívio são absorvidas pela filosofia lógica. No ca-

\footnotetext{
(13) . - João de Salisbury, Metalogicus, P. L. (Migne), T. 199, Lib. I, Cap. XI, cl. 838. The Metalogicon of John of Salisbury, translated bby Daniel $\mathbf{D}$. Mc. Garry, University of Callfornia Press, Berkeley and Los Angeles, 1962,305 págs. Cf. pág. 33 .

(14) - Idem. P. L. T. 199, cl. 839, C. McGarry, pág. 36.
} 
pítulo III do Livro III Hugo trata do estudo das principais artes, usando um pelo outro os têrmos ciência e arte (15). Os antigos selecionaram sete ciências dentre as enumeradas para o ensino, pois quem as estuda fica preparado para a fácil aprendizagem das outras. Elas constituem os melhores instrumentos e rudimentos para o alcance da verdade filosófica. Foram denominadas Trivium e Quadrivium por serem caminhos (viae) pelos quais a mente chega aos arcanos da sabedoria. Assim é que Pitágoras ensinava por sete anos as sete artes liberais. A proficiência no estudo, peculiar a muitos autores antigos, sua fertilidade literária, advinham do pleno domínio dessas artes rudimentares. Mas os estudantes de hoje ou não querem ou não sabem aproveitar êsse estudo e por isso, ainda que muitos estudem, poucos são sábios. Hugo indica a seguir as obras que devem ser lidas e o método que se deve empregar.

A ampla concepção do saber apresentada por 'Hugo de São Vitor, a nova classificação das ciências que êle propõe e que vai determinar um nôvo programa de ensino, resultou do desenvolvimento de cada uma das ciências do trívio e do quadrívio, da irrupção dos novos conhecimentos, particularmente matemáticos, provenientes dos gregos por intermédio dos árabes ou dos próprios árabes e, principalmente, do conhecimento e da gradual penetração no ensino do Organon aristotélico.

\section{IV}

Qual era, entretanto, o conteúdo das matérias e os instrumentos de trabalho para o ensino efetivo?

Para o ensino da Gramática aos principiantes recorria-se à Ars Minor e à Ars Major de Donato, que ensinara em Roma cêrca de $350 \mathrm{~d}$. C. O texto clássico do ensino gramatical eram as Institutiones de Prisciano (16), que lecionara em Constantinopla por volta de 500 d. C. As Institutiones dividiam-se em duas partes: o Priscianus Major, os 16 primeiros livros, tratavam da morfologia e o Priscianus Minor, os dois outros, versavam sôbre sintaxe (17). Os textos que

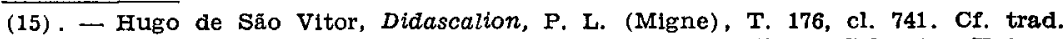
de Jerome Taylor, The Didascalion of Hugh St. Victor, Columbia University Press, New York and London, 1961, 254 págs.

(16). - Prisciani Caesariensis Grammatici Opera, edit. Augustus Krehl, Volumen Primum cont. De arte grammatica libros XVI, Lipsiae, In Libraria Weldmannia, 1819, 646 págs.; Volumen Secundum cont. Libros duos de constructione et reliquos libellos omnes, 1820, 638 págs.

(17). - Para tôda esta parte consulte-se Haskins, The Renaissance of the 12th century, New York, Meridian Books, 1957, 437 pags. Cf. chap. V, The Latin Language, pág. 127. Publications de l'Institut d'études Médlévales d'Ottawa, A. Paré, A. Brunet. P. Tremblay, La Rennaisance du XIIe Siècle - Les écoles et l'enseignement, Paris, Libr. Philosophłque J. Vrin, 1933, 324 págs. 
serviam para a leitura inicial do latim eram os Dísticos do chamado Catão, as Fábulas de Aviano, a Egloga de Teódulo. Os dicionários correntes eram Alphabetum do italiano Papias, o Panormia do inglês Osbern, o livro das Derivações de Hugúcio, professor de Bolonha e bispo de Ferrara. No fim do século alcançam bom êxito os glossários dos vocábulos mais usuais, como o de Adão da Ponte Pequena e o de Alexandre Neckam. Só no século XIII é que aparecem as gramáticas versificadas como o Doctrinale de Alexandre de Villedieu (1199) e o Graecismus de Everardo de Béthune (1212).

Um exame das bibliotecas da época revela os livros que serviam para a leitura e a interpretação de textos dos alunos mais adiantados no estudo da gramática, assim como para o entretenimento dos estudiosos em geral. E' verdade, como observa Haskins, que bliblioteca não significava então um edifício especial e nem sequer habitualmente uma sala. Comumente o têrmo aplicava-se a um armário, donde o anexim: Claustrum sine armario est quasi castrum sine armamentario.

Só as bibliotecas de grandes instituiç̃ões como os mosteiros de Toul, Cluny, Corbie, etc., é que reuniam centenas de volumes de obras profanas e religiosas.

E' neste tempo que começam a aparecer os livreiros que se encarregam do comércio dos manuscritos e da multiplicação dos exemplares. Difunde-se também no mundo das escolas o processo da reportatio, transcrição de aula ou sermão, destinada à circulação e feita por aluno ou escriba.

O estudo da gramática incluía o conhecimento dos bons autores, paradigmas da língua literária. Vergílio foi o principal poeta da Idade Média suplantado no século XII por Ovídio, de cujas obras eram preferidas as Metamorfoses, a Arte de Amar e os Remédios do Amor. Outros poetas lidos e estudados: Horácio, cujas Sátiras e Epístolas eram preferidas às Odes e Epodes; Estácio, Lucano, Pérsio, Marcial, Juvenal, Claudiano, Plauto. Lucano também era considerado historiador e Horácio e Juvenal eram tratados mais como moralistas do que como literatos e estilistas.

Entre os prosadores avultavam: Cícero, que para os medievais foi mestre da eloquiência e da moral; Sêneca, Quintiliano, Macróbio, Plínio, o Velho, Aulo Gélio, Frontino. Nem sempre se liam tais clássicos nos textos originais. Suas principais fontes para o estudante do século XII eram os excertos da gramática latina de Prisciano e as antologias (florilegia) .

Além das obras da Antiguiidade clássica, as bibliotecas dispunham de bíblias, em geral com muitas cópias; livros litúrgicos, obras dos Santos Padres, especialmente de São Jerônimo, Santo Agostinho, São 
Gregório Magno; obras dos escritores da Idade Média incipiente, os transmissores da cultura antiga como Marciano Capella, Boécio, Santo Isidoro de Sevilha, São Beda, o Venerável; obras jurídicas, especialmente de direito canônico: coleções de cartas pontifícias, cânones dos Concílios, o novo Decreto de Graciano; obras históricas, agiográficas, crônicas e documentação locais (do mosteiro, da catedral).

Estudantes e sacerdotes tinham seus próprios livros, assim como reis e príncipes letrados como Henrique de Champagne. Nas bibliotecas dessa época havia livros que podiam ser emprestados, como nas atuais bibliotecas circulantes e os que só podiam ser consultados no local, acorrentados para evitar possíveis fugas, mas acorrentados, "cathenati" ad communem utilitatem, em vista da utilidade geral (18) .

O ensino da Retórica antiga como em Cícero e em Quintiliano visava a formar o orador. A retórica medieval cifrava-se principalmente no ensino da composição epistolar ou Dictamen. No século XII surgem breves manuais sôbre a arte de escrever cartas com a apresentação de modelos: o Breviarum de Dictamine, o Flores Dictaminum de Alberico de Monte Cassino. Outros foram escritos em Orleães e em Tours. Cícero e Quintiliano continuavam a ser lidos. Sabia-se dos preceitos da oratória. A tarefa dos dictatores, entretanto, era ensinar a redigir cartas, e preparar formulários que ajudassem o estudante a exprimir e comunicar suas necessidades, esperanças e sentimentos habituais .

Nas duas primeiras décadas do século XII o estudo da Dialética tinha por base a Logica Vetus, ou sejam, os dois primeiros livros do Organon aristotélico, Categorias e Peri hermeneias, em tradução de Boécio; a Isagoge de Porfírio, famosa introdução às Categorias, em tradução de Mario Vitorino, revista por Boécio e os comentários do próprio Boécio: um sôbre as Categorias, dois sôbre a lsagoge e o Peri hermeneias. Recorria-se também a outros tratados de Boécio: Silogismos Categóricos, Tópicos, Divisões, além das Definições de Mário Vitorino, dos Tópicos de Cícero e o Peri hermeneias de Apuleio.

$\mathrm{O}$ estudo da dialética, entretanto, não tratava só de lógica elementar, como também, devido à referência ao problema dos Universais, de teoria do conhecimento e de metafísica. O crescente desenvolvimento da Dialética no século XII é que irá ensejar a transformação, durante o século XIII, da Faculdade de Artes em Faculdade de Filosofia.

Outras obras que serviam a tal altura do ensino para o estudo da filosofia: A consolação da Filosofia, de Boécio; as obras de Cícero,

(18). - Haskins, idem pág. 85: "The chained Bible" which has been the object of so much virtuous indignation on the part of Protestants was chained for the purpose of insuring, not of restricting its use". 
Sêneca, Apuleio; Santo Agostinho, um fragmento do Timeu em tradução e com comentário de Calcídio e o comentário sôbre o Sonho de Cipião de Macróbio. As traduções do Fedão e do Menão feitas por Aristipo na $2^{\text {a }}$ metade do século não tiveram difusão nem repercussão no campo dos estudos.

O grande, acontecimento filosófico do século foi a introdução nas escolas do Organon completo de Aristóteles. Foi entre 1120 e 1160 que se divulgaram no Ocidente as partes do Organon que vêm a constituir a Lógica Nova (Primeiros Analíticos, Segundos Analíticos, Tópicos, Elencos Sofísticos) em contraposição à Lógica Vetus que predominava no ensino junto com alguns manuais muito usados na época, conforme o testemunho de João de Salisbury. Esse acontecimento aristotélico "vai transformar a velha dialética, arte do Trivium, numa teoria da ciência em que passa tôda a concepção grega do cosmo e da vida do espírito" (19). Como diz Southern (20), "a digestão da lógica de Aristóteles foi a maior tarefa intelectual do período que se estende do fim do século décimo ao fim do século doze". "Digestão" de influência determinante no aparecimento da teologia escolástica na mesma época.

O ensino do Quadrívio vivia das parcas noções oferecidas pelas obras matemáticas de Boécio e os trabalhos de Isidoro de Sevilha, Beda, Alcuíno, cheios de boa vontade e de pouca ciência. Tal ensino, todavia, vem a ser inteiramente refundido sob o impacto das traduções científicas de obras gregas e árabes durante o século XII.

Durante séculos o ocidente latino se alimentara com migalhas da lauta mesa cultural da sabedoria grega. O contacto dos estudiosos medievais com as obras clássicas dos gregos foi só indireto, através de algumas traduções e das vulgarizações empreendidas por autores romanos. Só no século XII é que os cristãos do Ocidente entram a tratar diretamente com a ciência e a filosofia da Grécia clássica. Christopher Dawson já estudou muito bem a razão da disparidade entre a cultura muçulmana e a cristã-ocidental da primeira Idade Média (20a). Um dos fatôres que a éxplicam é justamente o contacto imediato dos islamitas com o saber grego através dos cristãos do Oriente, contacto com o qual só iriam beneficiar-se em grande escala os ocidentais a partir do século XII por intermédio dos árabes.

(19) . - Paré, Brunet, Tremblay, idem, pág. 163.

(20) . - Southern, The making of the Middle Ages, New Haven, Yale University Press, 1953, 280 págs. Cf. págs. 181-182.

(20a). - Christopher Dawson, Ensayos acerca de la Edad Media, Aguilar, Madria, 1956, 335 págs. Consulte-se cap. VIII, págs. 174. 
$\mathrm{O}$ renascimento do século $\mathrm{XV}$ será bàsicamente literário, enquanto o do século XII não levou em conta as belas letras, exceto o entusiasmo, de início, pela leitura de alguns poetas e prosadores romanos, pois o interêsse geral dos intelectuais movia-se em tôrno das ciências, da filosofia e da teologia. Segundo De Ghellinck (21), a história do movimento intelectual do século XII é dominada por um fato de alcance incalculável:

"o primeiro encontro de uma síntese cristã elaborada com o auxílio de Platão e de Agostinho no curso de dez séculos e do conjunto da síntese profana, grega ou árabe, alimentada pela contribuição dos autores que marcaram. época na história do espírito humano".

O período anterior ao século XII distinguiu-se pela ignorância do grego, sem contar as parcas traduções de Boécio no século VI e cuja morte intempestiva fêz abortar a concretização de seu projeto de traduções de Platão e de Aristóteles, e a tradução, no século IX, da obra do Pseudo-Dionísio levada a cabo por Hilduíno e João Escoto. Após o esbarrondamento do Império Romano do Ocidente, a tradição grega persistiu no Império Romano do Oriente, especialmente em Constantinopla. No Oriente o saber grego difundiu-se através de traduções para o siríaco, o hebráico, o árabe e delas é que passará finalmente ao latim. Algumas traduções siríacas de Aristóteles e dos teólogos gregos permaneceram na Síria até a chegada dos árabes no século VII, enquanto outras foram levadas por exilados nestorianos para a Pérsia e, por conseguinte, para os árabes, após sua conquista (22). As traduções árabes foram feitas diretamente do grego, como no caso do Almagesto de Ptolomeu ou do siríaco e do hebráico.

À herança grega os árabes acrescentaram suas próprias contribuições, especialmente nos campos da medicina, da matemática e da astronçmia. As traduções latinas, feitas do grego e do árabe, de obras matemáticas e astronômicas irão revolucionar a matéria tradicional do Quadrívio, assim como as traduções de textos médicos gregos e árabes irão impulsionar os estudos de medicina e assim concorrer para o desenvolvimento das escolas médicas, criando a base material do nôvo saber para o aparecimento da Faculdade de Medicina. Antes mesmo das Cruzadas, Constantino, o Africano, italiano por adoção, já havia traduzido para o latim as Urinas, as Febres e as Dietas do judeu Isaac, os Aforismos, os Prognósticos e as Doenças Agudas de Hipócrates, os comentários de Galeno e ainda outras obras de origem bizantina e árabe, que servirão de manuais nas escòlas de medicina até ao fim do século XV.

\footnotetext{
(21). - Museum Lessianum - Section Historique, n.os 4-5, J. De Ghellinck, s. J. L'essor de ta littérature au XIIe Siècle, 2e. édition, Desclee de Brouwer, Bruxelles, 1955, 584 págs. Cf. pág. 240.

(22). - Haskins, idem, pág. 281.
} 
Os principais centros de traduções no século XII foram a Sicília e Toledo, embora também tenham cooperado para as traduções o Norte da Itália, especialmente Pisa; Barcelona, Tarragona, Segóvia, Leão, Pamplona na Espanha; Toulouse, Béziers, Narbonne e Marselha na França. O principal centro tradutor estava na Espanha. Por isso escreve Menéndez y Pelayo:

"París y Toledo compendían el movimiento de las ideas en el siglo XII" (23).

De Ghellinck ressalta o "ardor audacioso e a tenacidade" dos tradutores que afrontavam os riscos das viagens a regiões dominadas pelo Islão em busca dos bons textos, dos livros preciosos. Ele cita, mas critica, também, a opinião, segundo a qual, o encontro na Síria e na Palestina dos Cruzados do Norte e do Sul da França fêz chegarem as poesias dos trovadores do Languedoc ao conhecimento dos trovadores franceses do Norte.

Os tradutores representavam pela sua procedência a sêde de saber do Ocidente nesse tempo. Inglêses: Adelardo de Bath, Roberto de Chester, Daniel de Morley, Alfredo de Sareshel; Hermann, da Alemanha; Gerardo de Cremona, lombardo; Burgúndio, Hugo e Leão de Pisa, toscanos; dálmatas como Herman da Caríntia; flamengos como Roberto de Bruges; espanhóis como Hugo de Santalla, Domingos Gunsdissalvo; judeus como Pedro Afonso, João de Cevilha, Savasorda, Abraão ben Ezra. Recrutavam-se de diferentes gêneros de vida e de ocupação: leigos, monges, imperadores, reis normandos da Sicília, clérigos, bispos, cardeais e papas como Alexandre III.

$\mathrm{Na}$ Sicília, no tempo de Rogério, Eugênio, o Emir, traduziu a Optica de Ptolomeu e mais tarde, sob Frederico II, Miguel Escoto e Teodoro de Antioquia verterão para o latim obras árabes de zoologia.

(23) . - Menéndez y Pelayo, Marcelino, Historia de los heterodoxos españoles, I, Biblioteca de Autores Cristianos, Madrid, 1956, 1086 págs. Cf. Tomo III, L. III, Cap. I-IV, pág. 137.

A respeito das traduçóes veja-se além das citadas obras de Haskins, De Ghellinck, Paré, Brunet, Tremblay: Pierre Duhem, Le ysstème du monde, Tome III, Paris, Hermann, 1958; Angel González Palencia, Historia de la España Musulmana, Cuarta edictón revisada, Editorlal Labor, 1945, Cap. XVII, pág. 191; Jacques Risler, La civilisation arabe, Paris, Payot, 1955, Chap. XVIII, pág. 208; G. Menéndez Pidal, La Escuela de Traductores de Toledo in Historia general de las literaturas hispanicas, I, Editorial Barna, Barcelona, 1949, págs. 277-289; Biblioteca Romanica Hispanica - VI - Antologia Hispânica, Ramon Menéndez Pidal, Páginas de História Antigua - "Sicilia y España antes de las vísperas sicillanas in Mis páginas preferidas, Estudios linguísticos y históricos - 8 - Madrid, Editorial Gredos, 1957, 326 págs. Cf. pág. 168; R. Menéndez Pidal, La Espafia del Cid, Cuarta edición, V. II, Madrid, Espasa-Calpe, 1947, pág. 631; Renan, Averroès et l'averroîsme, troisième édition, Paris, Michel Lévy Frères Libraires Editeurs, 1866, pág. 203. 
Adelardo de Bath traduziu em 1126 as tábuas trigonométricas de alKhwarizmi e Roberto de Chester em 1145 a Álgebra do mesmo autor. O Almagesto de Ptolomeu, resumo da antiga astronomia, foi traduzido do grego por volta de 1160 e do árabe em 1175 . Antes de 1162 já se haviam traduzido a Meteorologia e o De Caelo de Aristóteles. Gerardo de Cremona traduziu do árabe obras de alquimia. As obras completas de Hipócrates e Galeno foram traduzidas, durante o século XII, em parte do grego por Burgúndio de Pisa, mas principalmente do árabe por Gerardo de Cremona, assim como os resumos e comentários dos árabes juntamente com os escritos médicos de Aliben-Abbas e do judeu Isaac. Pelo fim do século apareceu a tradução do Cânon de Avicena.

$O$ estudo da medicina, impulsionado por essas traduções, era feito nos séculos XII e XIII à base de textos e não de experimentação. Mas é preciso lembrar com Haskins que

$$
\begin{aligned}
& \text { "o progrcsso ulterior na ciência médica requeria então a com- } \\
& \text { pleta assimilação dos conhecimentos médicos do mundo antigo". }
\end{aligned}
$$

Em Toledo árabes e judeus, após a reconquista, continuaram a gozar de liberdade e tolerância. Aí o arcebispo Raimundo (11261151) organizou com o auxílio do arquidiácono de Segóvia, Domingos Gundissalvo, e de outros estudiosos o famoso colégio de tradutores, que verteram para o latim as traduções árabes dos textos gregos, principalmente de Aristóteles. O conjunto dessas versões árabe-latinas, devido especialmente a Gundissalvo auxiliado pelo judeu Avendauth-João de Sevilha, são conhecidas como as "Primeiras traduções toledanas de filosofia" (24). Gundissalvo teria traduzido os quatro primeiros livros da Física de Aristóeles; os quatro livros de De Caelo et Mundo; os dez primeiros livros da Metafísica; o De Scientiis de Alfarabi; os livros De Anima de Avicena; a Filosofia de Al-Gazâli e provàvelmente o Fons Vitae de Avicebrão (Ibn Gabirol), assim como obras de Alkindi e o misterioso Liber de Causis extraído de Proclo. Poder-se-iam ainda mencionar outras traduções das obras aristotélicas feitas por outros autores anteriormente e depois no século XIILI.

Em Bizâncio São João Damasceno e o patriarca Fócio nos séculos VIII e IX asseguraram com seus comentários a continuidade do pensamento grego, aristotélico e neoplatônico, representado também por Temístio, Proclo, o cristão João Filopão, o platônico Pselos,

(24). - H. Bédoret, Les premières traductions tolédanes de philosophie. Oeuvres d'Alfarabi, "Revue Néoscolastique de Philosophie", Tome 41, (février 1938, págs. 80-97; Oeuvres d'Avicenne (aout 1938), págs. 374-400. 
o Jovem (1018-1096) e que através de Pletão e Bessarião chegará aos platônicos do Renascimento Italiano (25).

Quando se verifica o volume, a variedade e a importância das traduções no século XII e o impacto que produziram nos espíritos, concorda-se plenamente com Paré-Brunet-Tremblay:

"Sem dúvida, jamais uma geração humana se encontrou tãó repentinamente de posse de um tal volume de ciência, de pensamcnto, de cultura" (26).

\section{VI}

Vimos que o Trivium, artes sermocinales, tinham por objeto a expressão do pensamento: gramática, retórica e dialética. O Quadrivium, artes reales, que vai ser dilatado pelo afluxo de novidades das traduções, aplicava o espírito às coisas, res: o número, o espaço, as esferas celestes, a harmonia. Esse agrupamento das sete disciplinas era lembrado fàcilmente através dos versos mnemotécnicos:

Lingua, tropus, ratio, numerus, tonus, angulus, astra.

Gram loquitur, Dia vera docet, Rhe verba colorat,

Mus canit, Ar numerat, Geo ponderat, As colit astra.

Durante o século XII o ensino da Etica adicionou-se ao estudo da Gramática. Obras poéticas de Ovídio e Horácio, por exemplo, e obras de Cícero servem de textos para o ensinamento moral. Isso é bem demonstrado por Philipe Delhaye (27):

"A conjugação da moral e da gramática não é só uma herança antiga ou o fruto de uma evolução para os medievais. Ela corresponde a um desejo profundo, à necessidade de justificar o estudo dos autores pagãos".

\section{VII}

O aumento do saber na área das artes liberais é causa material do crescimento, da expansão das escolas e do aparecimento da Faculdade de Artes.

A organização dos estudos médicos consequiente ao aumento de informações, pelo contacto com as obras médicas gregas, árabes e judias vai levar à formação da Faculdade de Medicina .

(25). - Jacques Chevalier, Histoire de la Pensée, II, La Pensée Chrétienne, pág. 258, Paris, Flammarion, Editeur, 845 págs.

(26) . - Paré, Brunet, Tremblay, idem, nota 17, pág. 169.

(27). - Analecta Mediaevalia Namurcensia. Hors Serie. - 2 - Philippe Delhaye, "Grammatica" et "Ethica" au XIIe Siècle, Editions Nauwelaerts, Louvain, 56 págs., 1958, cf. pág. 17. 
$O$ reavivamento da Jurisprudência, por sua vez, determinou a fundação de escolas particulares de Leis e logo da Faculdade de Direito.

Os antigos materiais da Jurisprudência foram preservados no Corpus Juris Civilis, que consistia no Código (codificação da legislação imperial); no Digesto (resumo das obras dos juristas romanos); nas Institutas (manual para uso dos estudantes de direito); nas $\mathrm{No-}$ velas (compilação das últimas leis de Justiniano). A expressão Corpus Juris Civilis designava o direito romano em geral, para distingui-lo do Corpus Juris Canonici.

Essa codificação do Direito Romano feita por Justiniano no século VI, assim como as compilações organizadas entre os povos bárbaros, constituiram, nos primeiros tempos da Idade Média, a lei das regiões mais romanizadas como partes da Itália e sul da França.

Com o ensino jurídico de Pepo em Bolonha no fim do século $\mathrm{XI}$ e com o impulso que à escola bolonhesa de leis imprimiu o famoso Irnério ou Guarnério cêrca de 1088, iniciou-se o renascimento dos estudos jurídicos, que leva à fundação da Faculdade de Direito. Irnério antes de lecionar direito em Bolonha, havia sido professor de artes liberais. Foi a aplicação da dialética ao conteúdo do Corpus Juris que concorreu para o estabelecimento da nova ciência jurídica, tal como o uso da dialética aplicada à Sagrada Escritura, às verdades da fé, determinou o surgimento da Teologia Escolástica. O processo didático da glosa, consequiência do estudo do texto, organiza-se em tôrno dos "livros sagrados" de Justiniano, fontes de autoridade, e foi praticado em todos os campos do ensino, no direito e na gramática, sôbre textos dialéticos e sôbre textos bíblicos.

Como observa Haskins, o reavivamento do Direito Romano não ocorreu no vácuo, mas estava estreitamente relacionado com os grandes movimentos da época. As novas atividades comerciais exigiam uma lei mais flexível e mais urbana. As cidades do norte da Itália, centros de comércio, vão preferir a lei romana aos costumes arcáicos e essencialmente rurais dos lombardos.

\section{VIII}

A Universidade de Paris surgiu como corporação de mestres e estudantes de artes liberais e de teologia.

\footnotetext{
"Salerno, escrevia um autor no início do século XIII, cura as doenças pela virtude da medicina; Bolonha arma com as leis os que devem sustentar processos; Paris dispensa com as artes o alimento que faz os fortes; Orleãcs nutre com leite dos autores antigos os que ainda estão no berço" (27a).
}

$\overline{(27 a) .-C f .}$ pág. 2, nota 2 . 
Aí está uma clara referência à fama de Paris como centro de estudo das artes liberais. Mas, sobretudo acrescenta o cronista Guilherme, o Bretão, em Paris "era lida a Sacra Página". Esta expressão designava o estudo da teologia, puramente escriturário, pois o texto da lectio, o texto oficial para o ensino teológico era a Bíblia. Durante o século XII efetua-se a grande viragem metodológica que transforma o estudo da teologia e inaugura o reino intelectual da Teologia Escolástica. A penetração da Dialética no estudo da Dogmática cristã (28) no Ocidente, operou-se lentamente no decurso dos 150 anos que precedem a época de Santo Anselmo e de Abelardo. Uma tentativa de exposição sistemática da teologia com o adminículo das categorias lógicas de Aristóteles já fôra realizada em função dos conflitos teológicos bizantinos, por São João Damasceno no século VIII. Só no século XII é que vai surgir obra paralela no Ocidente, com os Quatro Livros das Sentenças, de Pedro Lombardo, com a vantagem de apresentar-se esta como

"o reflexo da atividade teológica das escolas e das questões que aí eram debatidas; espécie de Corpus doctrinae que pouco a pouco acaba por elaborar-se como o têrmo de uma longa tradição" (29).

Alguns nomes da trajetória que, partindo do período carolíngio vai culminar na montanha de Santa Genoveva, donde a voz de Abelardo ecoará pela Europa, são os de João Vendières, Wolfgang de Ratisbona, Adalberão de Laon, Herigério de Lobbes.

João de Vendières recorre aos manuais escolares de Boécio para compreender o tratado da Trindade de Santo Agostinho. Wolfgang de Ratisbona fecha a bôca de um herege opondo-lhe a teoria de Boécio sôbre o acidente. Adalberão de Laon expõe o dogma trinitário, recorrendo aos subsídios fornecidos pelo Trivium. Herigério termina a discussão com um antagonista por meio de um potente silogismo...

O Vocabulário de Papias, pela metade do século XI e o Glossarium Salomonis do século $\mathrm{X}$ já atestam o sucesso da dialética pelo grande lugar que concedem ao vocabulário da Lógica. No século XI viveu a maior expressão nesses tempos do estudo especulativo e da exposição racional do dogma: Santo Anselmo, o primeiro que, numa síntese feliz, conjuga razão e fé, raciocínio e tradição. Mas o artífice, por excelência da aplicação da dialética à dogmática foi Pe-

(28) . - Beiträge zur Geschichte der Phllosophie des Mittelalters-Supplement-band, J. De Ghellinck, Dialectique et dogme aux Xe. XIIe Siècles, págs. 79-99, Munster, Aschendorffsche Verlagsbuchhandlung, 1913, 491 págs.

(29) . - Museum Lessianum - Section historlque no 10, J. De Ghellinck, Le Mouvement Théologique du XIIe Siècle, Bruges, Editions "De Tempel", 1948, 594 págs. Cf. pág. 6. 
dro Abelardo (30). Nos comentários sôbre a Epístola aos Romanos e sôbre o Hexameron, Abelardo intercala entre o comentário literal, a comparação das versões e as observações sôbre construção, a discussão de questões teológicas propondo uma Quaestio, anunciando uma solutio e assim, gradualmente, a quaestio, travamento de um debate, acrescenta-se à lectio, a simples interpretação do texto bíblico. A dialética começa a funcionar no terreno teológico. Foi graças a Abelardo que o têrmo teologia, anteriormente sinônimo de Sacra Página, Divina Página, Sagrada Escritura, Divinitas e o que se the refere, passou a designar uma ciência ensinada nas escolas, distinta da exegese. Foi Abelardo que inaugurou o uso do têrmo teologia em seu sentido moderno. Sua primeira grande obra intitulou-se: "Teologia Cristã" e mais tarde êle compôs uma "Introdução à Teologia" (31) .

\section{IX}

A orientação dos estudos em Paris exprime notàvelmente o sentido da vida intelectual predominante na Alta Idade Média. Assim como o estilo gótico simboliza nas agulhas líticas das catedrais o sursum corda do cristão medieval, assim as obras escritas pelos pensadores e todo o labor do ensino volviam-se para o mergulho no Oceanum Divinitatis (32) . E' o sentido sacral da Idade Média em sua expressão culminante e que impregnava todos os setores da existência. Aliás, a subordinação das artes liberais ao estudo das verdades religiosas, a redução do programa escolar a uma função propedêutica ao estudo da Bíblia e das ciências religiosas vem de longe, remonta ao fim da Antigüidade (33). Parece-me que o impulso primeiro nessa direção deve ser atribuído a Filão de Alexandria. Filão com seu biblismo é o primeiro responsável pela sujeição completa dos estudos a um objetivo puramente religioso. Com sua mania de interpretar alegòricamente a Bíblia, para nela vislumbrar tôda a sabedoria dos filósofos, diz êle que não podemos ser impregnados pela virtude, Sara, sem antes nos acasalarmos com sua escrava, sendo a escrava da sabedoria a cultura obtida através dos primeiros estudos escolares.

\footnotetext{
(30). - Paré, Brunet, Tremblay, idem nota 17, pág. 239. A respelto de Díalética e Teologla Escolástica consultar: Martin Grabmann, Die Geschichte der scholastichen Methode, Graz, 1957, Akademische Druck - V. Vérlagsanstalt, especialmente o $2^{\circ}$ volume; Joseph Pieper, Scholastik, Gestalten und Probleme der mittelalterlichen Philosophie, München, Kösel-Verlag, 1960, 254 págs.

(31). - Paré, Brunet, Tremblay, idem, nota 17, pág. 309.

(32). - A propósito da analogia entre as artes, a filosofia e a religiáo na Idade Média, veja-se: Erwin Panofsky, Gothic Architecture and Scholasticism, New York, Merldian Books, 1959, 156 págs.

(33). - De Ghellinck, idem, nota 29, apêndice II ao cap. I, pág. 93.
} 
"Os grandes temas, diz Filão, exigem grandes introduções. O maior de todos os temas é a virtude, que empregará como introdução a gramática, a gcometria, a astronomia, a retórica, a música e tôdas as outras disciplinas intelectuais, que são simbolizadas por Agar, a escrava de Sara".

Sim, eis o fautor da redução das artes liberais à mera propedêutica da religião, da Bíblia. Sara é a virtude, o ideal do sábio. Agar, a cultura profana, as artes liberais.

Outro autor que me parece ter influenciado o espírito dos autores cristãos e medievais, dispondo-os para tal atitude em relação às disciplinas intelectuais, é Sêneca, cuja obra filosófica esteve em voga no século XII. A impressão causada pela epístola 88 das Cartas a Lucílio não era de molde a infirmar a influência de Filão exercida através de Orígenes, de São Jerônimo e de Santo Agostinho sôbre os autores medievais. Veja-se o título da citada carta: Artes liberales in bonis non esse, nihil ad virtutem conferre, (as artes liberais não são bens nem contribuem em nada para a virtude).

- Para que servem?

- Ad alia multum, ad virtutem nihil.

- Por que as ensinamos a nossos filhos?

- Não porque possam proporcionar a virtude, mas apenas porque preparam a alma para recebê-la.

Orígenes, em Alexandria, estudou as obras de Filão e em sua carta a Gregório (34) recomenda o uso das disciplinas circulares (enkyklia) como prelúdio para o Cristianismo, para a doutrina cristã como um fim:

Está traçado assim o programa de uma cultura cristã, cujo melhor regulador para a Idade Média será Santo Agostinho com seu De Doctrina Christiana, que moldará estritamente a cultura medieval. Diz o Bispo de Hipona que se os filósofos, especialmente os platônicos, emitiram idéias verdadeiras e conformes à fé cristã, devemos reclamá-las para nosso uso como se a reclamássemos de injustos possessores. E' o tema dos "despojos dos egípcios", tema de predileção desde Orígenes até ao fim da alta Idade Média (35).

(34). - Filáo, On mating with the preliminary studies, idem nota 4: Origenis Epistola ad Gregorium, P. G. Tomus XI, Origenes, t. I, cI. 87-92.

(35). - Marrou, Saint Augustin et la fin de la culture antique, idem nota 6 , trolsième partie: Doctrina Christiana, pág. 329; Bibliothéque Augustiniense, Oeuvres de Saint Augustin - XI. De Doctrina Christiana, Paris, Desclée de Brouwer, 1949, 606 págs. Cf. pág. 331. Sôbre os "despojos dos egípcios", cf. nota complem. 46, pág. 582. Sóbre a Escritura e a sa- 
No século XII Hugo de São Vítor indica claramente a maneira como as artes (gramática, retórica, dialética, aritmética, geometria, astronomia, música e mais a física) se subordinam à ciência divina (36):

"a sabedoria inferior retamente ordenada conduz à superior, a sabedoria divina, à qual se chega pelo estudo da divina Escritura. Dêsse estudo procedem o conhecimento da verdade e o amor da virtude, et haec est vera reparatio hominis".

\section{(Continua) .}

bedoria profana, I. II, cap. 42, pág. 337. Os escritores eclesiásticos, ao comentarem o eplsódio da fraude perpetrada pelos israelitas, por ocasiajo de sua partida do Egito (Exôdo, IIr, 22; XII, 35-36), reconheclam o direito dos cristáos a se aproveitarem das verdades que as doutrinas pagãs contivessem, pois as verdades pertencem a Deus.

(36). - Hugo de Sancto Victore, De Sacramentis, Prologus, Cap. VI: Quomodo omnes artes subserviunt divinae sapientiae, P. L. T. 176, cl. $185-D e$ Scripturis et Scriptoribus Sacris, Caput XIII, De fructu divinae lectionis, P. L. T, 175, cl, 20. 